\section{Lime Requirement for New Jersey Blueberry-producing Soils}

\author{
J.R. Heckman, ${ }^{1}$ G.C. Pavlis, ${ }^{2}$ \\ and W.L. Anastasia ${ }^{3}$
}

\begin{abstract}
Additional Index wOrds. soil pH, soil acidity, limestone, lime incubation, liming value determination, lime recommendation, Vaccinium corymbosum
\end{abstract}

Summary. In New Jersey, the major soil series (Sassafras, Pocomoke, Berryland, Atsion, and Downer) used for blueberry (Vaccinium corymbosum L.) production often have soil $\mathrm{pH}$ levels much lower than the soil $\mathrm{pH}$ range of 4.0 to 5.2 that is considered satisfactory for blueberry. The lime requirements for these soils to achieve a target soil $\mathrm{pH}$ of 4.8 has not been established. Soils with current soil $\mathrm{pH}$ levels in the range of 3.3 to 3.9 were collected from eight New Jersey sites used for blueberry production. The soils were treated with various application rates of calcium carbonate $\left(\mathrm{CaCO}_{3}\right)$ and incubated in a greenhouse to estimate the lime requirement of each soil. After 70 days of incubation with $\mathrm{CaCO}_{3}$, results show that a general lime recommendation of $100 \mathrm{lb}$ of calcium carbonate equivalent (CCE)/acre (112 kg.ha $\left.{ }^{-1}\right)$ for each one tenth of a soil $\mathrm{pH}$ unit increase desired would elevate $\mathrm{pH}$ of each of the soils to within a range ( $\mathrm{pH} 4.3$ to 5.0$)$ that brackets the target $\mathrm{pH}$ of 4.8 without causing serious risk of overliming.

$\mathrm{B}$ lueberries (Vaccinium corybosum) grow best in acid soils within a relatively narrow soil $\mathrm{pH}$ range. A soil $\mathrm{pH}$ range of 4.0 to 5.2 is generally satisfactory for blueberry (Austin et al., 1986; Austin and Bondari, 1992; Cummings et al., 1981; Harmer, 1944). Extremely low soil $\mathrm{pH}$ values $(<4.0)$ are detrimental to plant growth (Spiers, 1984). A recent

${ }^{1}$ Extension specialist in soil fertility, Plant Science Dept., Rutgers Univ., 59 Dudley Road, New Brunswick, NJ 08901-8520

${ }^{2}$ County agricultural agent, Atlantic County Cooperative Extension, 6260 Old Harding Highway, Mays Landing, NJ 08330-1533.

${ }^{3}$ Graduate student, P.O. Box 332, Bradley Beach, NJ 07720. review (Gough, 1996) of blueberry culture suggests that 4.8 is the optimum $\mathrm{pH}$.

In New Jersey, the soil series most often used for blueberry production are Sassafras, Pocomoke, Berryland, Atsion, and Downer (Table 1). The soil survey of Atlantic County, N.J. (Johnson, 1978), describes the reaction of the Sassafras series as medium acid ( $\mathrm{pH} 5.6$ to 6.0), the Downer series as very strongly acid $(\mathrm{pH} 4.5$ to 5.0) and the Pocomoke, Berryland, and Atsion series a extremely acid $(\mathrm{pH}$ below 4.5). After many years of cropping these soils to blueberry, receiving annual applications of about $60 \mathrm{lb} /$ acre of nitrogen $(\mathrm{N})\left(67.2 \mathrm{~kg} \cdot \mathrm{ha}^{-1}\right)$ as ammonium-N (Eck, 1988), these soils may become increasingly acidic. The lime requirements of these soils to achieve a target soil $\mathrm{pH}$ of 4.8 has not been established. Traditionally, most lime recommendation databases were developed to achieve target $\mathrm{pH}$ levels ranging from 6.0 to 7.0 (Mclean, 1982). Rough estimates of soil lime requirements for blueberry are unacceptable because the consequences of excessive lime application may lead to a deficiency of iron and other micronutrients (Haynes and Swift, 1985). Raising the soil $\mathrm{pH}$ too high can also promote conversion of ammonium nitrogen to nitrate, a form of nitrogen less available to blueberry (Townsend, 1970). The objectives of this study were to survey commercial blueberry fields for soil $\mathrm{pH}$ and to develop a database using the lime incubation method to determine lime requirements for important New Jersey soils used for blueberry culture.

\section{Materials and methods}

Soil test reports from samples submitted during 2000 for 104 commercial blueberry field sites in Atlantic and Burlington Counties, N.J., were obtained from records at the Rutgers Soils Laboratory. From these reports, soil $\mathrm{pH}$ data were examined by frequency distribution (Fig. 1).

Acid soils with $\mathrm{pH}$ values less than 4.0 were collected from the surface 6 inches $(15 \mathrm{~cm})$ of eight commercial blueberry farms in Atlantic County, N.J. The taxonomy, $\mathrm{pH}$, and organic matter content of each soil are shown in Table 1. Particle-size analysis was determined by the hydrometer method (Gee and Bauder, 1986). Soil organic matter concentration was determined by the modified Walkley-Black method (Walkley and Black, 1934).

Lime requirement was determined by incubation (Offiah and Fanning, 1994) using powdered $\mathrm{CaCO}_{3}$ (Fisher Analyzed Reagent), which had a CCE of $99.2 \%$. Various rates (Fig. 1) of $\mathrm{CaCO}_{3}$ [in increments equivalent to 50 , 100 , or $200 \mathrm{lb} /$ acre $(56,112$, or 224 $\mathrm{kg} \cdot \mathrm{ha}^{-1}$ ) assuming that the surface 6 inches of an acre of soil weighs $2 \times 10^{6}$ $\mathrm{lb}(15 \mathrm{~cm}$ of a hectare of soil weights $\left.\left.2.24 \times 10^{6} \mathrm{~kg}\right)\right]$ were added to $7.1 \mathrm{oz}$ $(200 \mathrm{~g})$ of air-dried soil held in styrofoam cups. Amended soil samples were mixed thoroughly with a spatula and placed in a greenhouse on a bench. The soils were incubated for $70 \mathrm{~d}$ with alternating wet and dry cycles. Greenhouse temperatures ranged from 21 to $30^{\circ} \mathrm{C}(70$ to 86 $\left.{ }^{\circ} \mathrm{F}\right)$. At the conclusion of the incubation period, the soils were air-dried and homogenized with a spatula. Soil $\mathrm{pH}$ values were determined with a $\mathrm{pH}$ meter using 1 soil : 1 water volume ratio. The $\mathrm{pH}$ values were correlated to additions of $\mathrm{CaCO}_{3}$ to determine lime requirement for each soil separately (Fig. 2) and group of eight soils collectively.

\section{Results and discussion}

The frequency distribution of soil $\mathrm{pH}$ data (Fig. 1 ) shows that $35 \%$ of the blueberry field soil samples had initial $\mathrm{pH}$ levels less than 4.0 , and $81 \%$ have $\mathrm{pH}$ levels lower than the target $\mathrm{pH}$ of 4.8. Clearly, there are many blueberry production sites that need to be limed.

The soils from the eight blueberry fields used in the lime incubation study had a soil $\mathrm{pH}$ range of 3.3 to 3.9 and mean of 3.7 (Table 1). They are representative of soils that have become excessively acidic and need lime amendment to raise soil $\mathrm{pH}$ to the level of 4.8 considered optimum for blueberry. The soils also have a wide range of soil organic matter contents (Table 1). Particle-size analysis revealed that this group of soils was very uniform in texture. Except for the Sassafras soil, which had $2.6 \%$ clay, the soils all had less than $0.05 \%$ clay. Sand contents ranged from $98 \%$ to $85 \%$ with a mean sand content of 93\%.

The lime incubation relationships presented in Fig. 2 show how soil pH increases with lime application rate. In the range of interest for blueberry production, the relationships are effectively linear. Calculations of the amount of lime required to raise $\mathrm{pH}$ of each individual soil by one tenth of a unit within 


\begin{tabular}{|c|c|c|c|c|}
\hline Site & Taxonomy of the soil series & $\mathbf{p H}$ & $\begin{array}{l}\text { Organic } \\
\text { matter } \\
(\%)\end{array}$ & $\begin{array}{c}\mathrm{CCE}^{\mathrm{z}, \mathrm{y}}(\mathbf{l b} / \mathbf{a c r e}) \\
\text { to raise soil } \\
\text { pH by } 0.1\end{array}$ \\
\hline 1 & Sassafras: Typic Hapludult; fine-loamy, siliceous, mesic & 3.6 & 1.0 & 143 \\
\hline 2 & Pocomoke: Typic Umbraquult; coarse-loamy, siliceous, thermic & 3.9 & 3.7 & 143 \\
\hline 3 & Berryland: Typic Haplaquod; sandy, siliceous, mesic & 3.9 & 3.6 & 250 \\
\hline 4 & Berryland: Typic Haplaquod; sandy, siliceous, mesic & 3.4 & 3.9 & 167 \\
\hline 5 & Atsion: Aeric Hapludult; sandy, siliceous, mesic & 3.3 & 4.5 & 143 \\
\hline 6 & Atsion: Aeric Hapludult; sandy, siliceous, mesic & 3.5 & 4.5 & 143 \\
\hline 7 & Downer: Typic Hapludult; coarse-loamy, siliceous, mesic & 3.8 & 2.0 & 125 \\
\hline 8 & Downer: Typic Hapludult; coarse-loamy, siliceous, mesic & 3.9 & 0.5 & 111 \\
\hline
\end{tabular}

${ }^{\mathrm{z}} \mathrm{CCE}$ requirements were estimated for each soil based on the equations shown in Fig. 2.

y $\left(1 \mathrm{lb} /\right.$ acre $\left.=1.12 \mathrm{~kg} \cdot \mathrm{ha}^{-1}\right)$.

the range of interest for blueberry production show the amounts of lime required for the eight soil ranged from 111 to $250 \mathrm{lb} /$ acre CCE (124 to 280 $\mathrm{kg} \cdot \mathrm{ha}^{-1}$ ) and had a mean of $153 \mathrm{lb} / \mathrm{acre}$ (17l kg.ha $\left.{ }^{-1}\right)$ (Table l).

When the general relationship of soil $\mathrm{pH}$ increase with the lime application rate $($ in $\mathrm{lb} /$ acre where $\mathrm{llb} /$ acre $=$ $1.12 \mathrm{~kg} \cdot \mathrm{ha}^{-1}$ ) was examined for the eight soils collectively, the following equation provided the best fit: $\mathrm{y}=-0.000000 \mathrm{~lx}^{2}$ $+0.0011 \mathrm{x}+3.70$ with an $\mathrm{r}$ value of 0.76 . Using this equation, the calculated amount of lime amendment suggests that the general lime recommendation for New Jersey blueberry soils is approximately $100 \mathrm{lb} /$ acre CCE for each one tenth of a soil $\mathrm{pH}$ unit increase desired.

We examined the consequences of applying this general recommendation of $100 \mathrm{lb} /$ acre CCE per onetenth unit increase to raise the $\mathrm{pH}$ of each of the individual soils to 4.8. On average for eight soils, applying this recommendation would result in a soil $\mathrm{pH}$ of 4.7, slightly below the target of 4.8. In the worst case scenario (Downer loamy sand-site 8), following the general lime requirement recommendation would result in a soil $\mathrm{pH}$ of 5.0. In the case of the Berryland sand - site 4 , the general lime requirement rec- ommendation would have resulted in a soil $\mathrm{pH}$ of 4.3 . Because a soil $\mathrm{pH}$ range of 4.0 to 5.2 is generally satisfactory for blueberry, we conclude from the results of this study that a general lime recommendation of $100 /$ acre CCE for each one tenth of $\mathrm{pH}$ unit increase desired will place these in a soil $\mathrm{pH}$ range that is satisfactory for blueberry production. Alternatively, when the soil series is known, the lime requirement values given in Table 1 may be used. The above lime requirement recommendation may not, however, apply to soils with a significantly different soil texture or organic matter content than the soils examined here.

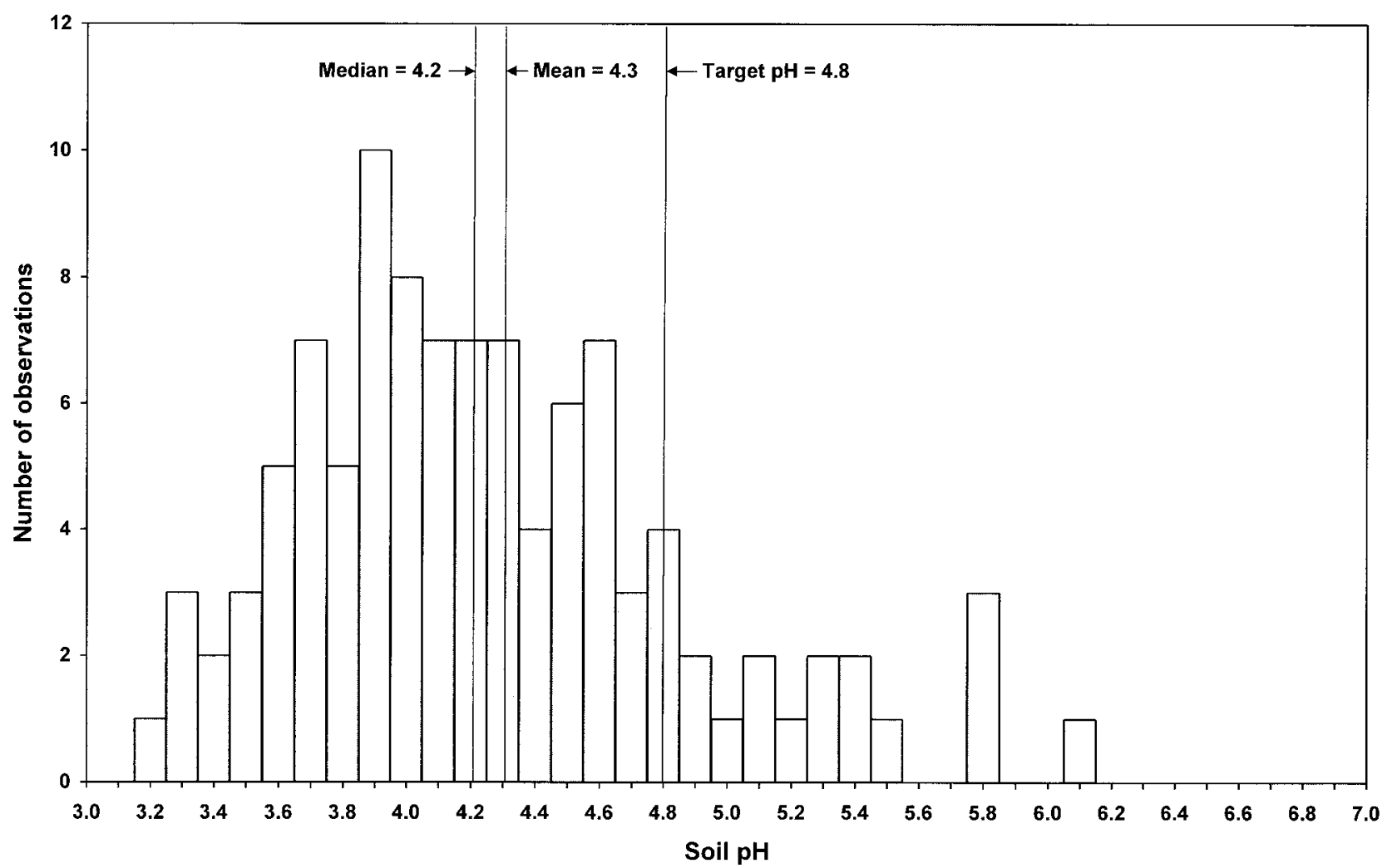

Fig. 1. Frequency distribution of soil pH values from 104 commercial blueberry soil samples collected during 2000. 


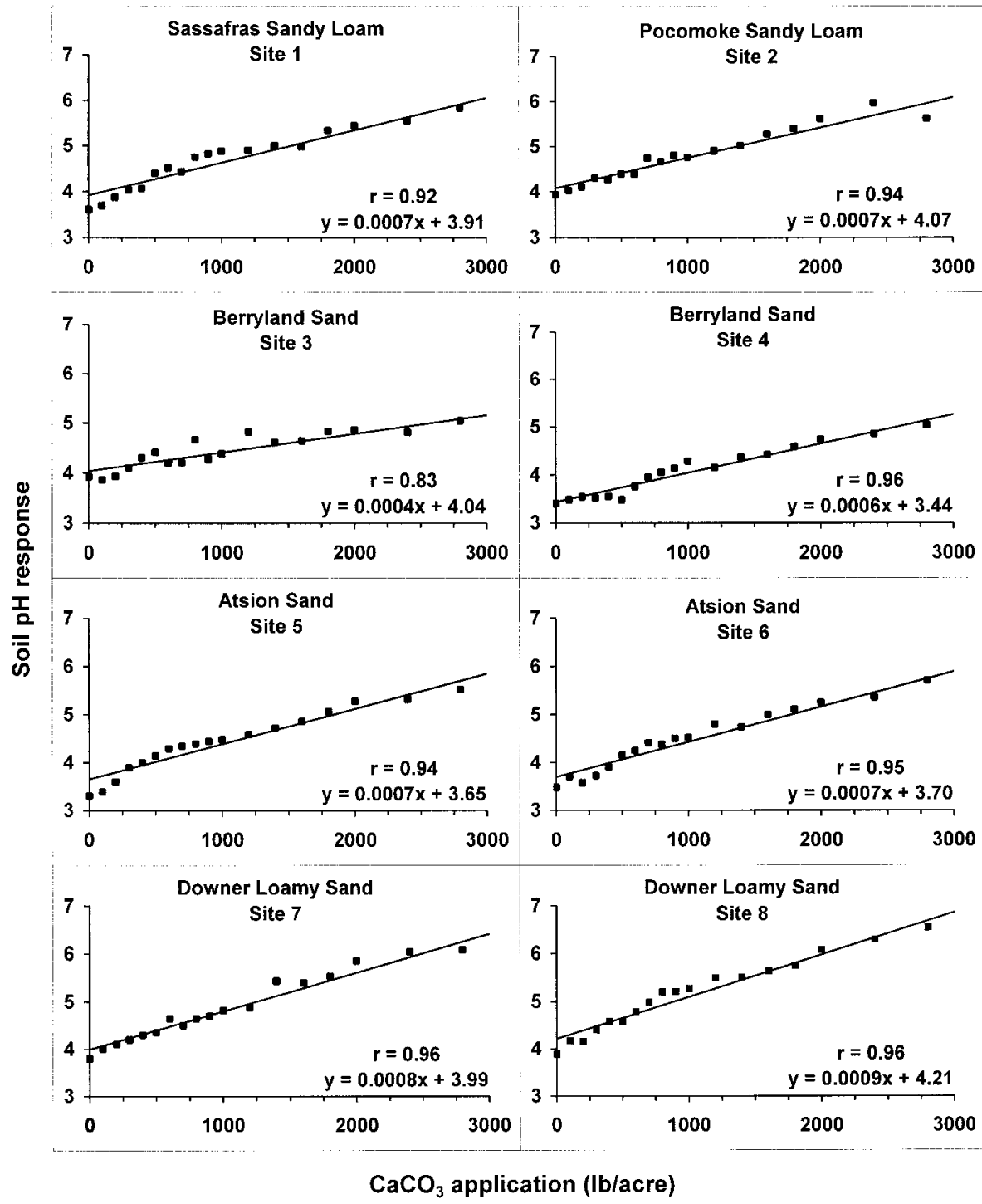

Fig. 2. Soil $\mathrm{pH}$ as affected by application rate of calcium carbonate $\left(\mathrm{CaCO}_{3}\right)$ to blueberry-producing soils from eight different New Jersey sites $\left(1 \mathrm{lb} / \mathrm{acre}=1.12 \mathrm{~kg} \cdot \mathrm{ha}^{-1}\right)$.

\section{Literature cited}

Austin, M.E. and K. Bondari. 1992. Soil pH effects on yield and fruit size of two rabbiteye blueberry cultivars. J. Hort. Sci. 67:779-786.

Austin, M.E., T.P. Gaines, and R.E. Moss. 1986. Influence of soil pH on soil nutrients, leaf elements, and yield of young rabbiteye blueberries. HortScience 21:443445

Cummings, G.A., C.M. Mainland, and J.P. Lilly. 1981 Influence of soil $\mathrm{pH}$, sulfur, and sawdust on rabbiteye blueberry survival, growth, and yield. J. Amer. Soc. Hort. Sci. 106:783-785.

Eck, P. 1988. Blueberry science. Rutgers Univ. Press, New Brunswick, N.J.

Gee, G.W. and J.W. Bauder. 1986. Particle size analysis, p. 383-441. In: A. Klute (ed.). Methods of soil analysis. Part 1. $2^{\text {nd }}$ ed. ASA and SSSA, Madison, Wis., Agron. Monogr. 9

Gough, R.E. 1996. Blueberries-North and south. J. Small Fruit Viticult. 4:71-106.

Harmer, P.M. 1944. The effect of varying the reaction of organic soil on the growth and production of domesticated blueberry. Proc. Soil Sci. Amer. 9:133-141.
Haynes, R.J. and R.S. Swift. 1985. Effects of liming on the chemical extractability of $\mathrm{Fe}, \mathrm{Mn}, \mathrm{Zn}$, and $\mathrm{Cu}$ and yheir uptake by highbush blueberry plants. Plant Soil 84:201-212.

Johnson, J.H. 1978. Soil survey of Atlantic County New Jersey. USDA Soil Conservation Serv., Wash. D.C

Mclean, E.O. 1982. Soil pH and lime requirement, p. 199-224. In: A.L. Page (ed.). Methods of soil analysis. part 2. $2^{\text {nd }}$ ed. ASA and SSA, Madison, Wis., Agron. Monogr. 9.

Offiah, O. and D.S. Fanning. 1994. Liming value determination of a calcareous, gypsiferous waste for acid sulfate soil. J. Environ. Qual. 23:331-337.

Spiers, J.M. 1984. Influence of lime and sulfur soil additions on growth, yield, and leaf nutrient content of rabbiteye blueberry. J. Amer. Soc. Hort. Sci. 109:599562.

Townsend, L.R. 1970. Effect of form of $\mathrm{N}$ and $\mathrm{pH}$ on nitrate reductase activity in low bush blueberry leaves and roots. Can. J. Plant Sci. 50:603-605.

Walkley, A. and I.A. Black. 1934. An examination of Degtjareff method for determining soil organic matter and a proposed modification of the chromic acid titration method. Soil Sci. 37:29-37.
Effects of a

Microbial

Inoculant on

Plant Growth and

Rhizosphere

Bacterial

Populations of

Container-grown Plants

\author{
Monica L. Elliott and \\ Timothy K. Broschat
}

\begin{abstract}
AdDitional INDEX WORDS.
Spathiphyllum, Hibiscus rosa-sinensis, Dypsis lutescens, areca palm, fluorescent pseudomonads, actinomycetes, heat-tolerant bacteria
\end{abstract}

Summary. A commercially available microbial inoculant (Plant Growth Activator Plus) that contains 50 microorganisms, primarily bacteria, was evaluated in a soilless container substrate to determine its effects on root bacterial populations and growth response of container-grown plants at three fertilizer rates. The tropical ornamental plants included hibiscus (Hibiscus rosa-sinensis 'Double Red'), spathiphyllum (Spathiphyllum 'Green Velvet') and areca palm (Dypsis lutescens). The bacterial groups enumerated were fluorescent pseudomonads, actinomycetes, heattolerant bacteria, and total aerobic bacteria. Analysis of the inoculant before its use determined that fluorescent pseudomonads claimed to be in the inoculant were not viable. The plant variables measured were plant color rating, shoot dry weight and root dry weight. Only hibiscus shoot dry weight and color rating increased in response to the addition of the inoculant to the substrate. Hibiscus roots also had a significant increase in the populations of fluores-

University of Florida, Ft. Lauderdale Research and Education Center, 3205 College Avenue, Ft. Lauderdale, FL 33314.

This research was supported by the Florida Agricultural Experiment Station, and approved for publication as journal series R-08513. The authors wish to thank Susan Thor, Elizabeth Des Jardin, and Lucy Fisher for their assistance in this project. 